\title{
EVALUASI KEPUASAN MAHASISWA TERHADAP PELAYANAN AKADEMIK FAKULTAS TARBIYAH DAN ILMU KEGURUAN IAI MUHAMMADIYAH SINJAI
}

\author{
Nurjannah \\ IAI Muhammadiyah Sinjai \\ Nurhaliza \\ IAI Muhammadiyah Sinjai \\ Eka Irmawati \\ IAI Muhammadiyah Sinjai
}

\begin{abstract}
This research was descriptive with a quantitative approach. Quantitative research involves measuring the level of certain characteristics. The subjects of the study were all students of the Faculty of Tarbiyah and Teacher Training, Islamic Institute of Muhammadiyah Sinjai. Data collection techniques using questionnaires and documentation. Based on the research results obtained that the evaluation of student satisfaction with academic services in the Faculty of Tarbiyah and Teacher Training based on 6 aspects of assessment namely tangibles aspects of 3.29, assurance aspects of 3.85, reliability aspects of 3.88, empathy aspects of 4.04, the responsiveness aspect is 3.81 and the information system aspect is 3.80. Based on these values, the six aspects are categorized as good. of the 6 aspects of the assessment, the highest assessment is on the assurance aspect while the aspect that needs to be improved is the tangibles aspect. Whereas the assessment of each study program the highest is Tadris Mathematics and the lowest is Arabic Education.

Keywords: Evaluation, Students' Satisfaction, Academic Service
\end{abstract}

\begin{abstract}
ABSTRAK
Jenis penelitian ini adalah deskriptif dengan pendekatan kuantitatif. Penelitian kuantitatif melibatkan pengukuran pengukuran tingkat suatu ciri tertentu. Subjek penelitian adalah seluruh mahasiswa Fakultas Tarbiyah dan IImu Keguruan Institut Agama Islam Muhammadiyah Sinjai. Teknik pengumpulan data menggunakan angket dan dokumentasi. Berdasarkan hasil penelitian diperoleh bahwa evaluasi kepuasan mahasiswa terhadap pelayanan akademik di Fakultas Tarbiyah dan Ilmu Keguruan berdasarkan 6 aspek penilaian yaitu aspek tangibles sebesar 3,29, aspek assurance sebesar 3,85, aspek reliability sebesar 3,88, aspek emphaty sebesar 4,04, aspek responsiveness sebesar 3,8I dan aspek information system sebesar 3,80. Berdasarkan nilai tersebut, keenam aspek dikategorikan baik. dari 6 aspek penilaian tersebut penilain tertinggi adalah pada aspek assurance sedangkan aspek yang perlu untuk ditingkatkan yaitu aspek tangibles. Sedangkan penilain setiap program studi yang tertinggi adalah Tadris Matematika dan yang terendah adalah Pendidikan Bahasa Arab.
\end{abstract}

Kata Kunci: Evaluasi, Kepuasan Mahasiswa, Pelayanan Akademik

\section{PENDAHULUAN}

Lembaga pendidikan merupakan suatu lembaga yang memberikan pelayanan pendidikan. Pendidikan merupakan salah satu modal penting untuk memajukan suatu bangsa karena kesejahteraan dan kemajuan sebuah bangsa dapat dilihat dari tingkat pendidikannya (Puspitaningtyas, 2019). Oleh sebab itu, kebutuhan masyarakat akan adanya pendidikan sangatlah meningkat terutama dalam pendidikan formal di perguruan tinggi. Semakin meningkat kebutuhan masyarakat terhadap pendidikan formal, khususnya pendidikan tinggi, menjadikan perguruan tinggi sebagai sektor strategis yang diharapakan dapat menghasilkan sumber daya manusia yang bermutu. Keadaan persaingan yang cukup kompetitif antar perguruan tinggi menuntut lembaga pendidikan memperhatikan mutu pendidikan dan kelembagaan sehingga mampu serta unggul dalam persaingan tersebut (Triono, 20I2).

Persaingan yang semakin ketat dan tuntutan kebutuhan masyarakat akan kualitas yang berorientasi pada nilai pengguna jasa (customer value) pada akhirnya menekan organisasi untuk dapat menggapainya dengan cepat (responsiveness). Menghadapi kondisi ini hal utama yang dapat di prioritaskan oleh perguruan tinggi adalah kepuasan mahasiswa. Kepuasan mahasiswa ditentukan oleh kualitas yang dikehendaki mahasiswa, sehingga jaminan kualitas menjadi prioritas utama bagi setiap perguruan tinggi, yang saat ini yang dijadikan sebagai tolak ukur keunggulan suatu perguruan tinggi (Alfiani, 20l6).

Era globalisasi saat ini, kualitas dipandang 
sebagai salah satu alat untuk mencapai keunggulan kompetitif, karena kualitas layanan merupakan salah satu faktor yang menentukan pilihan sesuatu yang memuaskan mahasiswa. Kepuasan mahasiswa akan tercapai apabila kualitas jasa yang diberikan sesuai dengan kebutuhannya. Kualitas layanan merupakan tingkat keunggulan untuk memenuhi keinginan mahasiswa (Rakasiwi, 20I5). Kualitas layanan adalah sejauh mana layanan yang diberikan oleh perusahaan sesuai dengan kebutuhan dan harapan dari pelanggan. Kualitas layanan akademik merupakan nilai yang diberikan oleh pelanggan sejauh mana layanan akademik yang diberikan sesuai dengan harapan pelanggan (Suffiyah, 20 I I).

Secara umum, kepuasan dapat diartikan sebagai kemampuan layanan atau produk untuk memenuhi kebutuhan pelanggan. Kepuasan sebagai evaluasi emosional yang menunjukan sejauh mana pelanggan percaya bahwa penggunaan layanan dapat menghasilkan perasaan positif (Martasubrata \& Suwatno, 2016). Kepuasan adalah perasaan senang dan kegembiraan yang individu dapat ketika kebutuhan dan keinginan mereka terpenuhi (Saif, 2014). Dengan demikian kepuasan merupakan evaluasi yang menggambarkan seseorang atas perasaan sikap senang atau tidak senang dalam beraktivitas (Susanto, 20I4).

Menurut Taman (2013) Kepuasan Mahasiswa adalah suatu bentuk seseorang yang mendapatkan pengalaman kinerja (atau hasil) yang telah memenuhi harapanya, yang meliputi; I) Waktu yang digunakan untuk menunggu dilayani, 2) Kecepatan dan ketepatan dalam pelayan kepada mahasiswa, 3) Ketepatan dalam melak-sanakan janji, 4) Keramahan dan kesopanan pimpinan, dosen dan dalam karyawan dalam bersikap dan berbicara, 5) Pengetaahuan dosen dan karyawan dalam pelayanan, 6) Prosedur dalam pelayanan dan penyesuaian layanan, 7) Kemudahan pimpinan, dosen dan karyawan dalam dihubungi, 8) Tempat pelayanan nyaman, bersih bagi mahasiswa, 9) Menciptakan kelancaran dalam pelayanan, 10) Keramahan pelayanan berpengaruh terhadap kepuasan mahasiswa.

Setelah mahasiswa mengikuti kuliah, mahasiswa akan merasakan tingkat kepuasan atau tingkat ketidakpuasan tertentu. Kepuasan adalah tingkat perasaan seseorang setelah membuat perbandingan antara kenyataan yang ia rasakan dengan harapannya. Menurut Nilakusmawati (20I4), Mahasiswa dapat mengalami salah satu dari tingkat kepuasan yang umum yaitu: (I) Jika kinerja di bawah harapan, mahasiswa akan tidak puas, (2) kalau kinerja sesuai dengan harapan, mahasiswa akan puas, (3) apabila kinerja melampaui harapan, mahasiswa akan merasa sangat puas, senang, atau bahagia. Perasaan tidak puas, puas atau sangat puas ini akan mempengaruhi tindakan selanjutnya.

Mahasiswa yang merasa puas akan menyampaikan secara positif tentang jasa yang dia gunakan/konsumsi. Mahasiswa yang tidak puas akan bereaksi secara berlainan. Mahasiswa yang tidak puas akan mengambil satu dari dua tindakan berikut ini: (I) mereka mungkin berusaha mengurangi ketidakpuasan tersebut dengan meninggalkan atau pindah ke program studi lain atau ke perguruan tinggi lain. (2) mereka mungkin berusaha mengurangi ketidakpuasan dengan mencari informasi yang dapat memperkuat nilai tinggi jasa tersebut (menghindari informasi yang mungkin memperkuat nilai rendahnya). Pimpinan/manajemen dapat mengambil langkah untuk meminimalkan jumlah ketidakpuasan mahasiswa, misalnya dengan mengadakan komunikasi secara periodik.

Komunikasi dengan para mahasiswa dapat dilakukan dengan menyediakan forum komunikasi yang baik bagi keluhan mahasiswa dan menangani keluhan tersebut dengan cepat. Harapan mahasiswa dibentuk oleh komentar teman dan kenalannya, serta informasi dan janji lembaga, dan pesaingnya. Apabila lembaga menaikkan harapan mahasiswa terlalu tinggi, mahasiswa mungkin akan kecewa jika lembaga gagal dalam memenuhinya. Di lain pihak, jika lembaga menetapkan harapan mahasiswa terlalu rendah, maka lembaga tidak dapat menarik cukup banyak calon mahasiswa meskipun mahasiswa akan puas. Tingkat kepuasan atau kesenangan yang tinggi akan menciptakan ikatan emosional yang tinggi. Lembaga perlu membentuk budayanya sedemikian rupa sehingga orang dalam lembaga bertujuan menyenangkan mahasiswa (Bhakti \& Rahmawati, 20I7).

Kualitas adalah sesuatu yang dinamis terus bergerak, jika bergerak maju dikatakan ada peningkatan mutu, jika bergerak mundur dikatakan mutunya. Kualitas dapat berarti superiority atau excellence yaitu melebihi standar umum yang berlaku. Menurut Sularso dimensi kualitas yang dipaparkan oleh beberapa ahli menjadi sangat penting untuk diperhatikan untuk memuaskan pelanggan (Marthalina, 2018). Terdapat tujuh dimensi dasar kualitas yaitu:

a. Kinerja, yaitu tingkat absolut kinerja barang atau jasa pada atribut kunci yang diidentifikasi para pelanggan. 
b. Interaksi pegawai, yaitu seperti keramahan, sikap hormat, dan empati ditunjukkan oleh masyarakat yang memberikan jasa atau barang.

c. Reliabilitas, yaitu konsistensi kinerja barang, jasa dan toko.

d. Daya tahan, yaitu rentan kehidupan produk dan kekuatan umum.

e. Ketepatan waktu dan kenyaman, yaitu seberapa cepat produk diserahkan atau diperbaiki, seberapa cepat produk infomasi atau jasa diberikan.

f. Estetika, yaitu lebih pada penampilan fisik barang atau toko dan daya tarik

g. penyajian jasa.

Sedangkan menurut Sviokla dalam (Sufiyyah, 20II): kualitas layanan adalah sejauh mana layanan yang diberikan oleh perusahaan sesuai dengan kebutuhan dan harapan dari pelanggan. Kualitas layanan akademik merupakan nilai yang diberikan oleh pelanggan sejauh mana layanan akademik yang diberikan sesuai dengan harapan pelanggan. Pelanggan dalam hal ini mahasiswa yang akan mengatakan layanan akademik itu berkualitas apabila sesuai dengan spesifikasi mereka. Dengan demikian, kualitas pelayanan akademik dalam penelitian ini adalah nilai yang diberikan mengenai seberapa bagus layanan akademik yang diberikan oleh Fakultas Tarbiyah dan Ilmu Keguruan mampu sesuai dengan harapan oleh mahasiswa.

Konsep yang digunakan untuk mengukur tingkat kualitas pelayanan pendidikan Fakultas Tarbiyah dan Ilmu Keguruan ini dilihat dari lima dimensi kualitas pelayanan jasa menurut Parasuraman, Zeithaml, dan Berry dalam (Farliana, 2017) yaitu tangible, reliability, responsiveness, assurance, dan empathy yang disebut dengan SERVQUAL. Masing-masing dimensi SERVQUAL dituangkan dalam beberapa atribut pertanyaan. Analisis univariat yang dilakukan ialah analisis kesenjangan antara harapan dan kenyataan mahasiswa, analisis tingkat kesesuaian kepuasan akan kualitas pelayanan, serta analisis uji beda. Hasil analisis kesenjangan tersebut kemudian dipetakan prioritasnya dalam ImportancePerformance Analysis.

Dyson mengartikan mutu layanan sebagai keluaran yang disampaikan dengan lebih baik dan terstandar melalui sebuah layanan. Kualitas pelayanan di sektor pendidikan khususnya di lembaga pendidikan tinggi adalah aspek fundamental dari keunggulan pendidikan (Malik, 2010). Sedangkan kepuasan mahasiswa merupakan evaluasi emosional berbagai hasil dan pengalaman yang beruhubungan dengan pendidikan yang benar benar mereka peroleh dibandingkan dengan harapan mereka sebelumnya (Sumaedi, 20II). Mutu layanan berpengaruh besar terhadap kepuasan mahasiswa dalam berbagai aspek. Inti dari kepuasan mahasiswa tergantung pada kualitas mengajar dan lingkungan belajar di institusi sebagai permintaan mahasiswa yang memenuhi syarat dengan baik, pembelajaran dan pengalaman fakultas untuk pelayanan akademik dan perkembangan profesional (Martasubrata \& Suwatno, 2016).

Institut Agama Islam Muhammadiyah Sinjai sebagai lembaga pelayanan pendidikan, terdapat perlimpahan kewenangan pengeloalaan pemenuhan jaminan kualitas terhadap mahasiswa kepada masing-masing fakultas. Termasuk Fakultas Tarbiyah Dan Ilmu Keguruan secara khusus mendapatkan pelimpahan kewenangan untuk menaungi program-program studi kependidikan. Sehingga desentralisasi tersebut, fakultas berkewajiban memenuhi jaminan kualitas.

Berbagai upaya yang dilakukan lembaga untuk meningkatkan pelayanan kepada mahasiswa misalnya memberikan pelayanan dengan cepat dan ramah, memberikan bantuan keuangan, menyediakan sarana dan prasarana. Sebagian besar mahasiswa merasa ada dosen yang kehadirannya dalam perkuliahan kurang, penggunaan jam mengajar yang tidak optimal, dan dosen kurang memberikan umpan balik atas tugas mahasiswa (Bhakti \& Rahmawati, 20I7).

Kepuasan mahasiswa terkait erat dengan kesesuaian antara harapan dan kenyataan dari kualitas pelayanan akademik di Fakultas Tarbiyah dan Ilmu Keguruan. Oleh karena itu, peningkatan kualitas pelayanan akademik di Fakultas Tarbiyah dan Ilmu Keguruan sangat dibutuhkan adanya proses evaluasi. Evaluasi terhadap layanan akademik dan kemahasiswaan, administrasi umum, keuangan, sarana dan prasarana yang dilakukan sebagai upaya untuk memperbaiki dan terus mengembangkan pelayanan di Fakultas Tarbiyah dan Ilmu Keguruan terhadap sivitas akademika, termasuk mahasiswa sebagai pengguna. Melalui proses evaluasi yang berkala seluruh bagian yang ada di lingkup Fakultas Tarbiyah dan Ilmu Keguruan memiliki kinerja yang professional dan dapat memberikan pelayanan yang sesuai yang diharapkan oleh mahasiswa.

Pelayanan publik di Fakultas Tarbiyah dan Ilmu Keguruan sampai saat ini sudah berjalan lancar, 
akan tetapi masih belum sepenuhnya memenuhi kualitas yang diharapkan oleh pengguna jasa khususnya para mahasiswa. Evaluasi dan peningkatan kualitas sangat diperlukan sebgai bentuk pengukuran tingkat keberhasilan layanan untuk mengetahui sebagai mana tingkat kepuasan mahasiswa. Berdasarkan pandangan tersebut peneliti mengangkat judul "Evaluasi Kepuasan Mahasiswa terhadap Pelayanan Akademik di Fakultas Tarbiyah dan Ilmu Keguruan”. Penelitian ini memfokuskan pada mahasiswa sebagai objek penelitian.

\section{METODE PENELITIAN}

Jenis penelitian ini adalah penelitian deskriptif dengan pendekatan kuantitatif. Adapun sampel dalam penelitian ini adalah mahasiswa Fakultas Tarbiyah dan IImu Keguruan IAI Muhammadiyah Sinjai. Teknik pengumpulan data menggunakan angket dan dokumentasi. Penelitian ini dilakukan secara intensif, peneliti ikut berpartisipasi di lapangan, mencatat secara hatihati apa yang terjadi, melakukan analisis reflektif terhadap berbagai dokumen yang ditemukan di lapangan, dan membuat laporan penelitian secara mendetail. Instrumen pengumpulan data berupa angket model skala likert yang terdiri atas dua bagian. Bagian pertama adalah kuesioner untuk mengukur persepsi responden mengenai mutu layanan akademik yang dijabarkan dari lima indikator yaitu tangibles (sarana pendidikan-alat perkuliahan, media pengajaran dan prasarana pendidikan), reliability (kehandalan dosen dan staf Akademik), responsiveness (Sikap tanggap), assurance (perlakuan pada mahasiswa), dan empathy (Pemahaman terhadap kepentingan mahasiswa). Kuesioner yang disusun oleh peneliti terdiri dari dua jenis yaitu:

a. Kuesioner data diri merupakan kuesioner untuk mengetahui data diri subjek.

b. Kuesioner kepuasan mahasiswa merupakan koesioner untuk mengukur kepuasan mahasiswa terhadap proses pendidikan yang dijalaninya sesuai dengan sistem yang ada di Fakultas Tarbiyah dan IImu Keguruan. Kuesioner ini terbagi menjadi 3 bagian yaitu proses belajar mengajar, proses administrasi dan fasilitas mahasiswa.

\section{HASIL PENELITIAN PEMBAHASAN}

Setelah kuesioner evaluasi kepuasan mahasiswa diisi oleh mahasiswa, selanjutnya dilakukan proses analisis data sehingga diperoleh hasil sebagai berkut:

Tabel I. Hasil Evaluasi Kepuasan Mahasiswa terhadap Pelayanan Akademik di Fakultas Tarbiyah dan IImu Keguruan

\begin{tabular}{|c|c|c|c|c|c|c|c|c|}
\hline \multirow[t]{2}{*}{ No } & \multirow[t]{2}{*}{ PRODI } & \multicolumn{6}{|c|}{$\begin{array}{l}\text { INDEKS RATA-RATA KEPUASAN } \\
\text { MAHASISWA }\end{array}$} & \multirow{2}{*}{$\begin{array}{c}\text { INDEKS } \\
\text { KUMULATIF } \\
\text { AKHIR }\end{array}$} \\
\hline & & A & B & C & D & $\mathbf{E}$ & $\mathbf{F}$ & \\
\hline I & PAI & 3.40 & 3.87 & 3.84 & 4.30 & 3.71 & 3.75 & 3.81 \\
\hline 2 & PBA & 3.02 & 3.78 & 3.73 & 3.35 & 3.56 & 3.70 & 3.52 \\
\hline 3 & PGMI & 3.36 & 3.89 & 3.90 & 4.01 & 3.83 & 3.81 & 3.80 \\
\hline 4 & TM & 3.58 & 4.08 & 4.11 & 4.29 & 4.20 & 4.13 & 4.07 \\
\hline 5 & TBI & 3.08 & 3.63 & 3.80 & 4.26 & 3.73 & 3.59 & 3.68 \\
\hline \multicolumn{2}{|c|}{$\begin{array}{l}\text { RATA- } \\
\text { RATA = }\end{array}$} & 3.29 & 3.85 & 3.88 & 4.04 & 3.81 & 3.80 & 3.78 \\
\hline
\end{tabular}

Keterangan: A (tangibles), B (reliability), C (responsiveness), D (assurance), E (emphaty), F (Information System)

Berikut disajikan indeks kumulatif akhir masing-masing Program Studi untuk memudahkan dalam membadingkan antara indeks komulatif akhir Program Studi yang satu dengan yang lainnya.

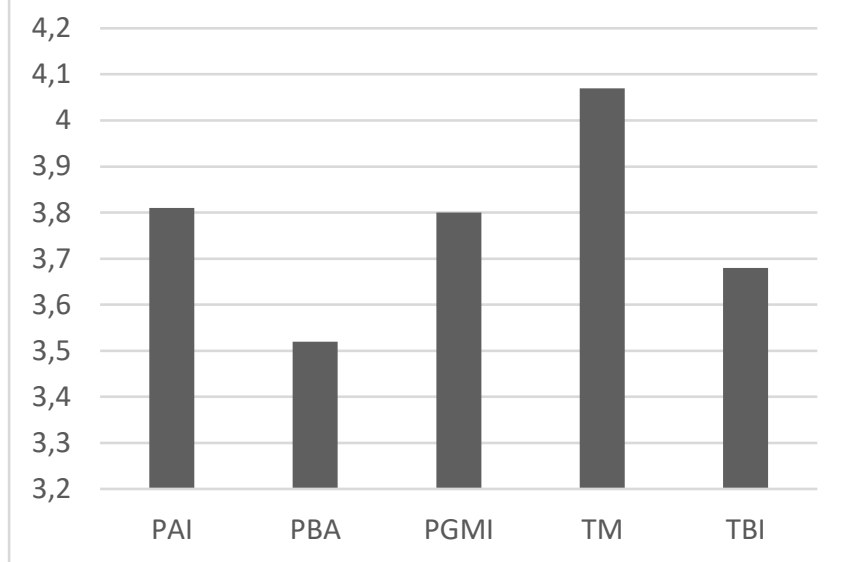

Gambar I. Hasil Evaluasi Kepuasan Mahasiswa setiap prodi terhadap Pelayanan Akademik di Fakultas Tarbiyah dan Ilmu Keguruan

Berdasarkan Tabel I dan Gambar I Hasil Evaluasi Kepuasan Mahasiswa terhadap Pelayanan Akademik di Fakultas Tarbiyah dan Ilmu Keguruan diperoleh nilai indeks rata-rata dari dari enam aspek penilaian dan 5 program studi sebesar 3,78. Indeks kumulatif tertinggi adalah Program Studi Tadris Matematika dengan skor 4,07, Pendidikan Agama Islam dengan skor 3,8I, Pendidikan Guru Madrasah Ibtidaiyah dengan skor 3,80, Tadris Bahasa Inggris dengan skor 3,68, dan Program Studi terendah adalah Pendidikan Bahasa Arab dengan skor 3,52. Apabila dirata-ratakan, maka kepuasan mahasiswa masih tergolong baik.

Berikut ini adalah gambar hasil evaluasi kepuasan mahasiswa terhadap pelayanan akademik yang disusun per-aspek indikator. Untuk memudahkan dalam membandingkan antara aspek yang satu dengan aspek lainnya. 


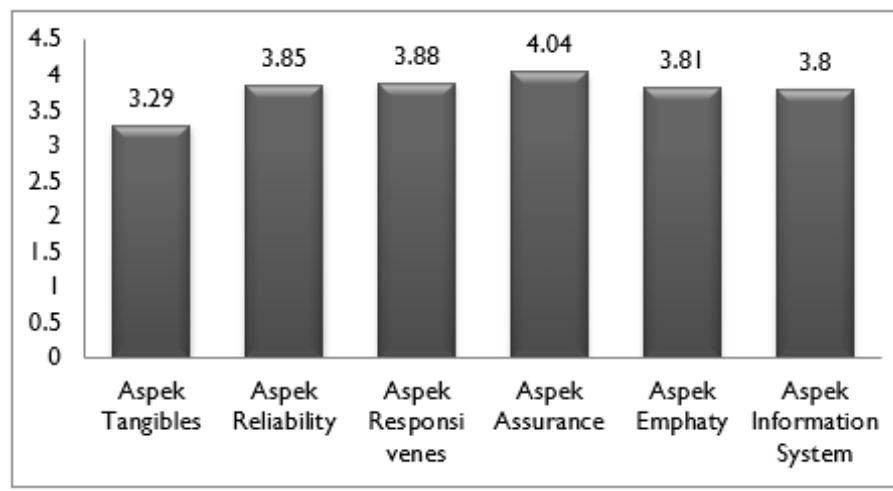

Gambar 2. Hasil Evaluasi Kepuasan Mahasiswa terhadap Pelayanan Akademik di Fakultas Tarbiyah dan IImu Keguruan per aspek

Berdasarkan Gambar 2 Hasil Evaluasi Kepuasan Mahasiswa terhadap Pelayanan Akademik di Fakultas Tarbiyah dan Ilmu Keguruan per aspek adalah aspek tangibles (3,29), reliability $(3,85)$, responsivenes $(3,88)$, assurance $(4,04)$, emphaty $(3,81)$, information system $(3,8)$. Terlihat jelas bahwa aspek yang tertinggi adalah aspek assurance (perlakuan kepada mahasiswa) yakni 4,04 dan aspek terendah adalah aspek tangibles (sarana pendidikan-alat perkuliahan, media pengajaran dan prasarana pendidikan). Hal ini mengindikasikan bahwa menurut mahasiswa, pelayanan akademik yang ada di Fakultas Tarbiyah dan Ilmu Keguruan masih kurang pada aspek tangibles yaitu berupa sarana Pendidikan, dalam hal ini alat-alat penunjang perkuliahan, media pengajaran serta prasarana Pendidikan lainnya. Adapun aspek tertinggi meliputi perlakuan kepada mahasiswa yang dengan jelas menyatakan bahwa perlakuan terhadap mahasiswa di Fakultas Tarbiyah dan Ilmu Keguruan sudah sangat baik.

Hasil tabulasi data menunjukkan kepuasan mahasiswa secara umum dinilai sudah memuaskan dengan nilai indeks rata-rata per aspek sebesar 3,78 . Kondisi ini dapat diasumsikan bahwa masih terdapat nilai ketidakpuasan sebesar I,22. Kekurangan tersebut jika ditinjau per aspek antara lain:

a. Aspek Tangibles (Keberwujudan)

Secara umum semua indikator kepuasan dinilai sudah memuaskan dengan nilai indeks rata-rata kepuasan aspek tangibles sebesar 3,29. Artinya Pelayanan Administrasi Akademik Fakultas Tarbiyah dan Ilmu Keguruan IAI Muhammadiyah Sinjai sudah cukup baik. Berdasarkan hasil kepuasan didapatkan bahwa masih terdapat I,7I nilai aspek yang masih belum memuaskan. Guna meningkatkan kepuasan mahasiswa perlu ada perbaikan. Indikator yang paling penting untuk diperbaiki adalah ketersediaan ruang kuliah yang bersih, rapi dan sejuk, ketersedian buku referensi di perpustakaan IAI Muahhamdiyah Sinjai, dan ketersedian kamar kecil yang cukup dan bersih.

b. Aspek Realibility (Kepercayaan)

Indikator realibility dinilai sudah memuaskan dengan nilai indeks rata-rata kepuasan 3,85. Artinya Pelayanan Administrasi Akademik Fakultas Tarbiyah dan Ilmu Keguruan IAI Muhammadiyah Sinjai sudah cukup baik. Hal ini menunjukkan bahwa masih terdapat I.I5 nlai aspek yang belum memuaskan. Guna meningkatkan kepuasan mahasiswa perlu ada perbaikan, yaitu Kemampuan staff dalam menjaga dan memperhatikan mahasiswa, akan menimbulkan rasa kepercayaan mahasiswa terhadap staff dan sistem operasional yang ada untuk menyelesaikan masalah mereka.

c. Aspek Responsiveness (Daya Tanggap)

Secara umum semua indikator kepuasan dinilai sudah memuaskan dengan nilai indeks rata-rata kepuasan aspek responsivennes sebesar 3,88 atau sudah baik. Hasil kepuasan masih menunjukkan adanya kecenderungan ketidakpuasan aspek sebesar I, 12, dengan demikian perlu adanya peningkatkan kepuasan pelayanan.

Indikator utama yang perlu untuk diperbaiki adalah pelayanan kepada mahasiswa secara efisien (cepat dan tepat waktu).

d. Aspek Empathy (Empati)

Secara umum semua indikator kepuasan dinilai sudah memuaskan dengan nilai indeks rata-rata kepuasan aspek empathy sebesar 4,04 atau baik. Hal ini menunjukkan bahwa antara mahasiswa dan petugas sudah terjadi hubungan komunikasi dan pemahaman kebutuhan yang baik. Berdasarkan hasil tersebut masih terdapat 0,96 aspek yang belum memuaskan.

Indikator utama yang perlu untuk ditingkatkan adalah pengaturan waktu oleh dosen dalam proses pembelajaran.

e. Assurance (Keyakinan)

Secara umum semua indikator kepuasan dinilai sudah memuaskan dengan nilai indeks rata-rata kepuasan aspek assurance sebesar 3,81 atau baik. Berdasarkan hasil tersebut masih terdapat 1,19 aspek yang belum memuaskan. Indikator utama yang perlu untuk ditingkatkan adalah memahami 
kepentingan dan kesulitan mahasiswa serta memahami bakat dan minat mahasiswa serta berusaha untuk mengembangkanya.

f. Information System (Sistem Informasi)

Secara umum semua indikator kepuasan dinilai sudah memuaskan dengan nilai indeks ratarata kepuasan aspek sebesar 3,80 atau baik. Berdasarkan hasil tersebut masih terdapat I,20 penilaian aspek yang belum memuaskan. Indikator utama yang perlu untuk ditingkatkan adalah informasi akademik dan pelayanan non akademik dalam bentuk website (online).

\section{KESIMPULAN}

Berdasarkan pembahasan di atas dapat disimpulkan bahwa pelayanan Akademik Fakultas Tarbiyah dan Ilmu Keguruan IAI Muhammadiyah Sinjai sudah memuaskan dengan nilai indeks ratarata sebesar 3,78. Hasil kepuasan ini berarti menunjukkan bahwa pelayanan yang diberikan oleh subbag pendidikan secara umum sudah baik. Ratarata kepuasan berdasarkan aspek menunjukkan bahwa semua sudah puas. Aspek tertinggi adalah aspek assurance sebesar 4,04 dan terendah aspek tangibles sbesar 3,29. Perolehan skor menunjukkan bahwa kepuasan tertinggi diraih oleh mahasiswa Tadris Matematika sedangkan terendah mahasiswa Pendidikan Bahasa Arab. Kondisi ini bisa jadi dipengaruhi oleh pengalaman dan intensitas dalam hal pelayanan. Pengalaman bisa dibentuk selama mahasiswa tersebut mengikuti perkuliahan.

Dari hasil analisis di atas dapat di berikan saran untuk meningktkan kepuasan mahasiswa ada beberapa hal yang harus diperhatikan terutama aspek tangibles, dimana aspek ini memiliki nilai indeks rata-rata paling rendah pada semua program studi. Ada beberapa hal yang harus diperhatikan antara lain: kebersihan ruang perkuliahan, kebersihan toilet, dan kelengkapan koleksi refrensi di perpustakaan, serta keramahan staff dan dosen.

\section{DAFTAR PUSTAKA}

Abdullah, T.S. (20I3). Analisis Kualitas Pelayanan Terhadap Kepuasan Mahasiswa Pada Fakultas Ekonomi Universitas Negeri Yogyakarta. Jurnal Fakultas Ekonimi, volum 2, nomor I. Yogyakarta: Universitas Negeri Yogyakarta.

Alfiani, A. (20l6). Kepuasan Mahasiswa Terhadap Pelayanan Administrasi Akademik Di Subbag Pendidikan Fakultas IImu
Pendidikan Universitas Negeri Yogyakarta. Skripsi. Yogyakarta: Universitas Negeri Yogyakarta.

Bhakti, Y.B \& Rahmawati. E.Y. (2017). Indeks Kepuasan Mahasiswa Terhadap Pelayanan Program Studi Pendidikan Matematika. jurnal Formatif, volum 7, nomor 3: Universitas Indraprasta PGRI Jakarta.

llyas. (20/4). Tingkat Kepuasan Mahasiswa Terhadap Layanan Akademik Dosen Pendidikan Agama Islam (Penelitian Pada Mahasiswa Semester II Fakultas IImu Pendidikan Universitas Negeri Semarang). Jurnal Penelitian pendidikan, vol. 3, nomor 2: Universitas Negeri Semarang.

Kasmari \& Marlien. (20/8). Tingkat Kepuasan Mahasiswa Terhadap Kualitas Pelayanan Pada Universitas Stikubank Semarang. Jurnal Dinamika Teknik, volume 9, nomor I: Universitas Stikubank Semarang.

Lupiyoadi, R. (20I3). Manajemen. Pemasaran Jasa. Jakarta: Salemba Empat.

Malik, M. E. (2010). The Impact of Service Quality on Student Satisfaction in Higher Education Insitutes of Punjab. Journal of Management Research, volum 2, nomor 2, I-II.

Martasubrata, N \& Suwatno, S. (20/6). Mutu Layanan Akademik Sebagai Determinan Kepuasan Mahasiswa (Academic Service Quality as Determinant of Student Satisfaction). Jurnal Pendidikan Manajemen Perkantoran, volum Inomor I, I36-143.

Marthalina. (20/8). Analisis Kualitas Pelayanan Akademik dan Kepuasan Mahasiswa di IPDN Kampus Jakarta. Jurnal MSDM, Vol. 5, Nomor I: I- 18. Institut Pemerintahan Dalam Negeri.

Nilakusmawati. (20/4). Faktor-Faktor penentu kepuasan mahasiswa terhadap pelayanan fakultas sebagai lembaga pensdidikan (Studi Kasus di FMIPA, Universitas Udayana). Cakrawala Pendidikan, volume 27, nomor 3.

Ogunode, N. J. (2020). The Evaluation Of The National Objectives On The Early Childhoodcare Education (Ecce) Programin Gwagwalada Areacouncil Of Fct, Abuja, Nigeria. Jisae: Journal of Indonesian Student Assessment And Evaluation, 6(2), $\quad 149 \quad-\quad 158$. Https://Doi.Org/10.21009/Jisae.062.05

Puspitaningtyas, A. (2019). Kualitas Pelayanan Pendidikan dalam Menganalisis Kepuasan Mahasiswa pada Program Studi Pendidikan 
Matematika. Jurnal Program Studi Pendidikan Matematika, volum, 8, nomor I. Lampung: UIN Raden Intan Lampung.

Rakasiwi, L. (20I5). Analisis Kualitas Pelayanan Akademik Dan Ketersediaan Sarana Akademik Biro Administrasi Akademik Terhadap Kepuasan Mahasiswa Universitas Muhammadiyah Surakarta. Naskah Publikasi. Surakarta: Universitas Muhammadiyah Surakarta.

Saif, N. I. (20I4). The Effect of Service Quality on Student Satisfaction: A Field Study for Health Services Administration Students. International Journal of Humanities and Social Science, volum 4, nomor 8, I72-181.

Sufiyyah, A. (20II). Pengaruh Kualitas Layanan Akademik dan Birokrasi terhadap Kepuasan Mahasiswa. Jurnal ISSN, volum 13 No. 2. 85-93.

Sugiyono. (20I2). Metode Penelitian Kombinasi (Mixed Methods). Bandung: CV. Alfabeta.

Sumaedi, S. (20II). The Effect of Student Perceived Service Quality and Perceived Price on Student Satisfaction. Management Science and Engineering, volum 5, nomor I, 88-97.

Susanto, H. (2014). Pengaruh Layanan Akademik terhadap Kepuasan Mahasiswa. Jurnal Pendidikan Terbuka dan Jarak Jauh, volum I5, nomor 2, 88-98.

Sutartiah, F. (2017). Evaluasi Kepuasan Mahasiswa Terhadap Kualitas Pelayanan Pendidikan Lembaga Pendidikan Tinggi ABC Di Cikarang. Jurnal Formatif, vol. 7, nomor I: 5665. Universitas Indraprasta PGRI.

Sulaeman, E., Rahayu, W., Kamaruddin, E., Widodo, W. A. T., \& Widodo, W. A. T. (2020). A THE FUNCTIONALITY OF THE MIDDLE VALUE OF THE INDONESIAN VERSION OF EMOTIONAL LEARNING INSTRUMENT. JISAE: Journal of Indonesian Student Assessment and Evaluation, 6(I), 26 - 46. https://doi.org//0.21009/JISAE.06I.03

Taman, A \& Sukirno. (20I3). Analisis Kualitas Pelayanan Terhadap Kepuasan Mahasiswa Pada Fakultas Ekonomi Universitas Negeri Yogyakarta. Jurnal Fakultas Ekonomi. Vol. II No. I. Tahun 2013. Yogyakarta: Universitas Negeri Yogyakarta.

Triono, M.J. (20I2). Kepuasan Mahasiswa Terhadap Layanan Administrasi Akademika Fakultas IAIN Walisongo Semarang. Skripsi.
Semarang: Institut Agama Islam Negeri Walisongo 